\title{
Public Space as a Public Good: Some Reflections on Public Space to Enjoy Solitude
}

\author{
By Urša Komac*
}

\begin{abstract}
This paper explores the public space as a public good. Public space is understood as a 'void' in the urban continuum that has unlimited access for the city dwellers. We study the public space as a physical, material space, as imaginative material space and as a formative part of the public domain in order to answer the following question: what are the aspects of public space that articulate the city? The public space is necessary for social and economic reasons. The city needs both spaces to socialise, meeting places, and above all, spaces for the enjoyment of solitude. A public park, for example, can at the same time fulfil both social needs. A public space is also economically efficient. It is unfeasible for each person to own a garden with majestic trees, a large pond and a vine-covered pergola. But many people could for example at the same time use a public park that has all these features. The public space as defined in this paper has the two characteristics that define a public good, namely non-excludability and non-rivalry. Public spaces are non-excludable by definition as everyone can access them. They can be, and sometimes are, to an extent nonrivalrous. That is, the enjoyment of a user does not detract from the enjoyment of any other. It follows that when users start to interfere negatively with each other's enjoyment the public good becomes congested and it is not able to perform all or some of its functions.
\end{abstract}

Artis sola domina necessitas.

Otto Wagner

This motto could be translated as "Necessity is art's only master", and although it originated with Semper, Wagner adopted it as his own. He used it to impress the students in the inaugural class of their first year. According to Wagner, there are a number of functional requirements that an architect needs to comply with down to the very last detail. He should choose his building materials wisely and they should be easy to work with, easy to maintain, durable and economical; and he should also opt for a simple, economical structure. Only after having taken these principles properly into account should he consider the question of the forms that would emerge from these premises, which should be in harmony with one another and should always be easy to understand. A work of art created in accordance with these precepts will always be in keeping with the style of its time. In fact, Wagner's architectural ideas were basically functionalist, thirty years before the start of the Modern Movement.

Let's begin with the necessitas - in other words, with the raison d'être of the public space as a place for spending time alone. In order to do so, we must

* Assistant Professor, The University of Canberra, Australia. 
provide a definition of public space that will resolve the apparent contradiction between "public" and "solitude". In this paper we also include comments on the many uses of public spaces and how these can give rise to certain problems. This is followed by a brief annotated history of the public space, in which we demonstrate how the need for public space has always existed and describe some of the places used to satisfy this need.

After discussing the need, we will look for the solutions. In other words, we will try to single out the features that will ensure that the spaces we have selected as examples will be to the liking of those persons looking for somewhere public in which to meditate in solitude. At the same time, we will provide other examples, or counter-examples, that may or may not meet these conditions.

And finally, in the last section, we will consider art. A space that is able to express eloquent silences is in itself art. The act of satisfying the need to find a place in which to meditate alone cannot be anything else but art. It is a spiritual need.

\section{Concerning Necessity: Definition of Public Space}

To begin at the beginning, we must start by defining the public space. A precise, concise definition is one that states that the public space is space to which access is unrestricted.

There are at least two reasons why it is necessary for a space to be accessible to everyone. One is what we might call the social dimension of the public space; in other words, the city must have meeting places that can be used by everyone. Another reason is the economic efficiency of the public space. Let us give an example: it would not be at all economical, or it would perhaps even be impossible, for each person to have a garden with majestic trees, a large pond and a vine-covered pergola attached to their home. But everyone could use a beautiful public park that has all these features, and they will want to use it at the same time. It is quite possible that to some extent the use that each one of them makes of the park will not disturb the others. So a large part of the public park may provide satisfaction to many people who, for example, like walking barefoot on the grass. From this point of view, the public space can be justified without it having anything to do with relating to other people. The public space for being alone is not only desirable but possible.

In most cases, when experts on architecture speak of the public space they are focusing solely on its social dimension, i.e. on the public space as a meeting place. They almost always tend to place the emphasis on one use of public space in particular and ignore other possible uses or the idea of compatibility between different uses. So frequently, in a somewhat stereotyped way, when they think of the public space they think of a square (a place for being) or a street (a place for moving along).

Spaces that are right for people on their own can also be appreciated and used in a different way. Some social uses can be perfectly compatible with 
solitude. Often the way in which society functions means that certain times are right for people on their own, such as mid-morning on a weekday.

However, it is relevant to question whether there are sufficient opportunities for people on their own in the contemporary city. The very shortage of public spaces, their overcrowding and people's lack of respect for others can make it difficult to enjoy being alone. In some cases, it might be possible to give priority to certain uses over others in a specific public place. But these rules - or, rather, suggestions - must be subtle. The very definition of public space prohibits any prohibition on access. Only bad behaviour and criminal acts can and must be dealt with by rules and regulations.

Reflecting on the need for space in which to be alone is nothing new. Friedrich Nietzsche, for example, wrote in the section 280 of The Gay Science ${ }^{1}$, entitled Architecture for the search of knowledge: "One day, and probably very soon, we need some recognition of what above all is lacking in our big cities: quiet and wide, expansive places for reflection. Places with long, high-ceilinged cloisters for bad or all too sunny weather where no shouting or noise of carriages can reach and where good manners would prohibit even priests from praying aloud / .../ We wish to see ourselves translated into stone and plants, we want to take walks in ourselves when we stroll around these buildings and gardens."

However, in Nietzsche's time it was relatively easy to find places in which to be alone, for the countryside began where the city ended. Pleasant walks could be taken in the outskirts, such as along the old city walls, or to the little chapel in the distance. Probably the chapel came first, and then the lane leading to it. The walk is a nice one because it only goes as far as the chapel and there are not many people around. Another delightful stroll, before it became filled with traffic, was along the road lined with chestnut trees. Nineteenth-century walkers knew all these places well, for they were people with plenty of time for leisure - like the walkers in Chekhov's stories, who often witnessed some seemingly trivial incident, or Werther, who from the shade of a linden tree watched Lotte passing by. A gentleman from a Jane Austen novel could afford an English garden with its appearance of untamed nature: its stream bubbling from under a rock, its abandoned windmill and its shady copse.

When cities began to grow and it became difficult to get out to the country for a walk, the solution was to bring an idealised piece of countryside into town. So, large public parks were built, such as the Bois de Boulogne, Hyde Park, Central Park, etc. In addition, with the improvements in living conditions, leisure time increased and more people began to consider going for a walk in the park. It is true that most of these spaces were not suitable for people on their own. It was the custom to go there precisely to see and to be seen, like Proust's Madame Swann. But if we look hard we realise that these parks are also full of hidden corners, of narrow, less frequented paths that lead

1. Friedrich Nietzsche, The Gay Science (New York: Vintage books. Random House, 1974), 226-227. In original see Die Fröhliche Wissenschaft (Stuttgart, Alfred Kroner Verlag), 213: "Es bedarf einmal und wahrscheinlich bald einmal der Einsicht, was vor Allem unseren grossen Städten fehlt: stille und weite, weitgedehnte Orte zum Nachdenken..." 
to places where we can take a rest and admire a waterfall, for example. Perhaps the best instance of this variety of uses is Olmsted's Central Park.

Another option in the past was churches, so cool and peaceful in summer and previously always open so that anyone could enter. ${ }^{2}$ The churches are still there but the most beautiful ones are filled with tourists at all hours. The less attractive ones are closed when there is no service being held, since there are fewer pious souls around and the clergy are afraid of thieves. What is more, we live in a secular society that aspires to give satisfaction to everyone on an equal footing. It is difficult to think of a Muslim, an atheist, an agnostic or a Jew going to meditate in a Catholic church.

A third option for a person wishing to be on its own, and perhaps the most romantic, is a cemetery.

The proximity to death invites reflection. A cemetery is certainly not a public square, but in theory it is open to everyone and is therefore a public space. And some cemeteries were actually designed for people to walk in. This is the case of the garden cemeteries of northern Europe, which to a certain extent imitate the Romantic art of, for example, Caspar David Friedrich. Probably the best example of this is Mount Auburn Cemetery, built in 1837, not in Europe but the United States, on the outskirts of Boston. A more modern example and one that is certainly a more inviting place for meditation is the Woodland Cemetery designed by Asplund and Lewerentz in Stockholm.

The trouble is that cities have become enormous, and it appears the number of places for people on their own has not increased in proportion. Spreading suburbs with motorway junctions invariably surround the new cities. And the nineteenth-century gardens in the city centre are too often overcrowded. It is easy to get to them on public transport, and as the number of people with free time to spend has increased enormously, these gardens are usually full. But maybe that is not such a bad thing, for it is now easier than ever to get lost in the crowd: walking along Broadway, following the rush-hour flow, letting oneself be carried along. However, it is conceivable that somebody occasionally thinks it would perhaps be nice not to have to worry about traffic lights or people shoving.

In short, perhaps the world today is more than ever in need of spaces for being alone.

Our study cases suggest certain characteristics that may make public spaces attractive to someone looking for a place in which to meditate. The most obvious are the presence of nature and what we could call memory. In other words, on the one hand, such places are all set in the countryside or are a piece of the countryside located in a more or less urban environment; and on the other hand, in all of them an important factor is the reference to a mythical past

2. A church is a place in which to relate to God and therefore a place for contemplation. During the consecration of a Catholic church the choir sings the motet: Locus iste a Deo factus est/inaestimabile sacramentum;/ irreprehensibilis est. (This place is made by God;/ inestimable sacrament; / it is irreprochable.) Anton Bruckner set this motet to music for the consecration of a church in Linz. 
that may contain some vestige of reality or may be entirely and deliberately invented.

\section{Concerning Nature}

The ancient philosophers liked to stroll through gardens as they pondered or discussed. In the novel El Árbol de la Ciencia (The Tree of Knowledge) by Pío Baroja, the principal character goes up to the flat roof of his uncle's house - an irritable bachelor doctor - and calls it "the garden of Epicurus". 3 According to this philosopher, the purpose of life is the search for pleasure. However, most pleasures bring pain and must therefore be avoided because they are simply not worth it. The only innocuous pleasure is the one we get from enjoying a garden and strolling around it alone or with a friend from time to time.

One of Omar Khayyam's disciples tells us: ${ }^{4}$ "I often used to hold conversations with my teacher, Omar Khayyam, in a garden, and one day he said to me, 'My tomb shall be in a spot where the north wind may scatter roses over it.' I wondered at the words he spoke, but I knew that his were no idle words. Years after, when I chanced to visit Nishapur, I went to his final resting-place, and it was just outside a garden, and trees laden with fruit stretched their boughs over the garden wall, and dropped their flowers upon his tomb, so that the stone was hidden under them."

The Chinese poet Wang Wei, writing during the Tang dynasty in the eighth century, also described in many of his poems the attractions of nature for someone on their own:

Seated alone among close bamboos,

I pluck the strings and hum.

In the depth of the forest there is nobody.

Only the moon watches me.

$[\ldots]$

In line, the slim willows

Reflect their inverted images in the waves.

My new hut by the Meng wall;

among aged trees, fallen leaves of willows. ${ }^{5}$

\footnotetext{
3. See: Pio Barroja, El árbol de la ciencia (Madrid: Caro Raggio. Catedra., 1994), 166. 41.

4. Edward Fitzgerald, Rubáiyát of Omar Khayyám. (London and Glasgow: Collins, 1947), 40-

5. Wang Wei, La montaña vacía [Laughing lost in the mountains] (Madrid: Ediciones Hiperion., 2004), 73.
} 
An interesting combination of East (China during the Tang dynasty) and West (Mitteleuropa) appears in Gustav Mahler's "Das Lied von der Erde" (The Song of the Earth). The lyrics are taken from translations by Hans Bethge of various Chinese poets, published under the title Die Chinesische Flöte (The Chinese Flute). ${ }^{6}$ These poets include Li Tai Po and Mong Kao Jen in addition to Wang Wei. Mahler is a unique composer, among the last of the Romantics and the Expressionists, a Jew who became a Catholic, director of the Vienna Opera House, the Metropolitan Opera House and also the Ljubljana Opera House. Two of these lieder are of particular interest: "Der Einsame in Herbst" (The lonely one in Autumn, by Chang Tsi):

\section{Herbstnebel wallen bläulich überm See; \\ Vom Reif bezogen stehen alle Gräser; \\ Man meint, ein Künstler habe Staub von Jade \\ Über die feinen Blüten ausgestreut. ${ }^{7}$}

And "Der Abschied" (The Farewell) includes a poem by Mong Kao Jen and another by Wang Wei; the last verses are by Mahler himself. Here the music expresses with greater precision the feelings described in the poem:

\section{Still ist mein Herz und harret seiner Stunde! \\ Die liebe Erde allüberall \\ Blüht auf im Lenz und grünt aufs neu! \\ Allüberall und ewig blauen licht die Fernen! \\ Ewig... Ewig...}

The classics also show a love of solitariness in nature, far from the negotium of the city. The Bacchic poems portray an idealised life in the countryside where nature can be enjoyed. One example is Horace's Epode 17/2, which begins:

\section{Beatus ille qui procul negotiis, ut prisca gens mortalium, ${ }^{9}$}

These verses were paraphrased by Fray Luis de León, a poet of the Renaissance:

6. "Die Chinesische Floete," in CD Mahler Das Lied von der Erde (Erato Disques S.A., 1992), 24-26.

7. Ibid, 26. "Autumn mists drift over the lake. / The grass is covered with frost, / As if an artist had thrown jade dust / Over the delicate blooms."

8. Ibid, 32-35. "Still is my heart, it is awaiting its hour! / Everywhere the lovely earth blossoms / forth in spring and grows green anew / everywhere, forever, / horizons are blue and bright! / For ever and ever ..."

9. Horace, The complete Work of Horace (London: J.M. Dent \& New York: Sons, 1908), 113. Happy the man who far from business cares / like the pristine race of mortals... 
¡Qué descansada vida

la del que huye del mundanal ruido

y sigue la escondida

senda por donde han ido

los pocos sabios que en el mundo han sido! ${ }^{10}$

It is easy to find numerous instances of pleasant places for a person on their own in which contact with nature plays an essential role. In Spain there are three excellent examples beside the sea.

In San Sebastián, Eduardo Chillida's sculpture Wind Comb, where the waves play on the steel and stone and the wind blows through the empty spaces, sounding like a huge flute and battering the viewer on all sides.

Another interesting example is the memorial to Walter Benjamin in Portbou, on the French frontier with Catalonia, by the sculptor Dani Karavan (see Figure 1). Here an ever-changing sea is framed in a kind of steel tunnel with steps inside it. As you go down through the tunnel, you see, hear and smell the sea in different ways that make a startling impact. It is also obvious that you should not go right to the end of the steps or otherwise you will fall over the edge: Memento mori.

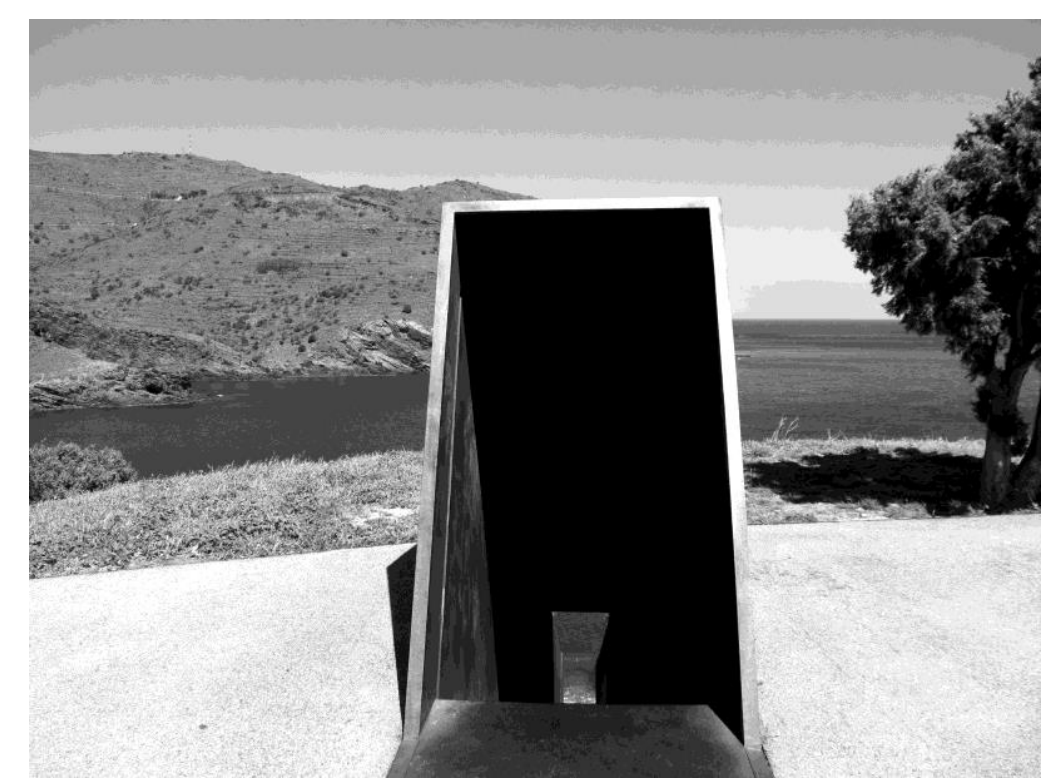

Figure 1. Dani Karavan. Passage: Homage to Walter Benjamin. Portbou Source: Courtesy of Wikipedia Commons.

The third example is the cemetery at Finisterre in Galicia, designed by César Portela and located on the side of the cape giving onto the estuary (see

10. Fray Luis de Leon, retrieved from http://users.ipfw.edu/jehle/poesia/vidareti.htm. [19.9.2016]. "How restful is the life / of he who shuns the daily bustle / and follows the hidden path / trodden by the few wise men / this world has known!" 
Figure 2). Bleak cubes of concrete, placed beside an unpaved path running down the edge of the cliff, contain niches and a chapel. The blocks emerge from the earth like granite tors, or perhaps more like megalithic monuments erected in the heather. Nobody is buried in this cemetery. The aesthetic objections raised by the inhabitants of Finisterre meant that this is one of the few places that is almost always a space for those in search of solitude, lizards and the odd person sunbathing on the concrete blocks.

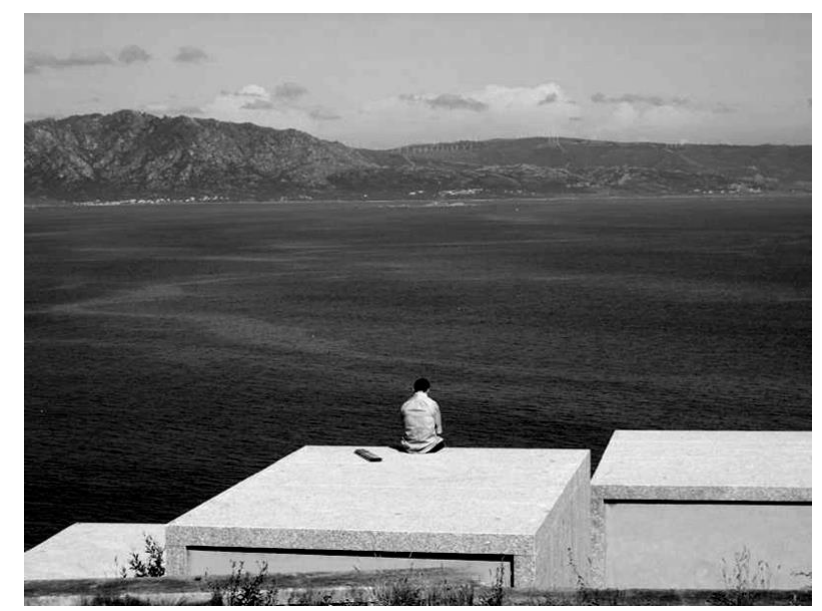

Figure 2. César Portela. Cemetery of Finisterre Source: Pablo Guillén.

However, it is not so easy to find spaces in which a person on their own can be comfortable and which are completely unconnected with the world of nature. We could mention a few eminently urban locations, such as the Plaça de Sant Felip Neri in Barcelona. It contains a fountain and trees - acacias with transparent leaves that give shade and change the colour of the paving stones according to the season of the year. It is an ideal place from which to gaze up at a patch of blue sky in summer, or better still in winter through the bare branches. But water, sky and acacias are still nature. Another urban example that might be a good place for a person alone is the Praza da Quintana in Santiago de Compostela. Here the greenish-grey granite of the cathedral in the rain bears the weight of nature.

It is even more difficult to find examples that are further removed from nature and more man-made. Although, with a stretch of the imagination or an effort of memory, it is possible to recall that corner of some airport in which we had to spend three hours waiting for a connection to fly somewhere. The bench was comfortable, it was raining, and for once the mobile phones were not a nuisance. It was late and there was almost nobody around. Through a window we could see the planes taking off. It was pleasant there, not having to speak to anyone, and the hours sped by. We were able to spend time thinking and putting our thoughts in order for when we returned home.

Leaving aside the extreme cases, it would seem reasonable to believe that nature plays an important part in the spaces that are the subject of this study. We could venture an explanation, which is that before civilisation spread 
almost everywhere, it reached no more than a short way beyond the edges of the city. It was therefore very easy to have access to nature - a more or less untamed nature - in which to stroll and think.

\section{Concerning Memory}

It could be said that culture is memory. It is difficult to imagine a place that is detached from a cultural context. Even a virgin forest is affected by cultural connotations through the person observing it for the first time. Voltaire, whom Bogdanović so admired, wrote a story titled Aventure de la mémoire (Memory's adventure), ${ }^{11}$ which begins:

The thinking human race, that is to say, the one-hundred-thousandth part of all the human race, had believed for a long time, or at least had frequently repeated, that we only produced ideas through the senses, and that memory is the only instrument by which we could join two ideas and two words together.

This is why Jupiter, representing nature, fell in love with Mnemosyne, the goddess of memory, as soon as he saw her; and from that marriage the new Muses were born, who were the inventors of all the arts.

So there is no place that has been visited that is unconnected with culture, i.e. with memory. But this memory can be reduced to a minimum. Some architecture is the consequence and the victim of fashion, which by its very nature is fleeting and easily forgotten.

Memory is of great importance in the public spaces of Bogdanovic and Plečnik. It is the memory of a mythical, real or invented past. Plečnik seems to have wanted to believe in the Etruscan past, and to a certain extent he plays with the Roman wall. Bogdanović was vaguely inspired by pre-classical architecture. If anyone suggests to him that there is an Etruscan element in his work he is delighted to hear it.

We can give other good examples of places for enjoying solitude in which memory plays a fundamental role. The Plaça de Sant Felip Neri could be considered one more instance of altered memory. The square still shows the effects of the bombing during the Spanish Civil War. The reconstruction by Florensa created a square that had previously been badly damaged. He mixed stone from different places to form a very special corner in Barcelona. The bullet marks on the wall of the church are a harsh and very real memory.

Ramón Otero Pedrayo describes the Praza da Quintana:

The upper end of the Praza das Praterías, with its venerable old paving stones, leads into the Praza da Quintana. This square is a cloister of the cathedral and of the city, a pool of silences and memories, where the

11. Voltaire, "Memory's Adventure," in Candide, Zadir and selected stories (New York: A Signet Classic, 1961), 325. 
twelve strokes of midnight resound in long, deep reverberations that shiver over the stones. It was originally a bustling market and then a cemetery, and this imbues it not with melancholy but with a grave, purifying nobility. A creation of the Baroque period, the Praza da Quintana formed the centre of Santiago at the east end of the cathedral and the cloister of the Holy Door, which endowed it with both a universal and a local value. It is not generous like the Portadas and the Hospital and the Praterías. Its architectural landscape is a combination of severe walls, inviting arcades for nocturnal walks, grand doorways, ample buildings and the apse of the cathedral. Despite this variety, plain walls are the predominant feature. ${ }^{12}$

Mnemosyne is everywhere in the landscaping by Dimitris Pikionis on the Philopappos Hill in Athens (see Figure 3). A visitor wishing to walk the Philopappou Hill, in the centre of Athens, must turn their back on the Acropolis. At the end of the path they will find the church of St. Dimitris Loumbardis and can pause to take refreshment in a little café while admiring the Parthenon on the hill opposite. Mass tourism is not concerned with the oblique ways of approaching sites, and so the Hill of Philopappou remains off the beaten track and reserved for solitary locals. Pikionis used stones from the archaeological museum excavations to pave the roads. And he himself decided exactly where each one of them was to go. He employed ancient and classical symbols either inscribed on the stones or else described in the manner in which they were placed.

12. Ramon Otero Pedrayo, Guía de Galicia [Guide to Galicia] (Vigo: Editorial Galaxia, 1965), 536-537: "El patín superior de La Platería lleva, con sus losas venerables, a la Quintana. Un claustro de la Catedral y la ciudad, un lago de silencios y recuerdos esta plaza pétrea, en cuyo ámbito las doce campanadas de la medianoche suscitan largas y profundas resonancias y corren como un temblor sobre las piedras. Fue mercado de tiendas de algazara y cementerio, y este carácter no le concede melancolía y sí una grave y purificadora nobleza. Creación del barroco, la Quintana quedó en el corazón de Santiago y a la cabecera de la Catedral como en el claustro de la Puerta Santa, y por esto es dueña de un doble valor universal y compostelano. No es generosa como Portadas como el Hospital y la Platería. Su paisaje arquitectónico combina severos muros, pórticos gratos al paseo nocturno, portadas en grande estilo, generosidades de pazo, con los ábsides de la Catedral. A pesar de tal variedad impone su norma el muro liso, /..." 


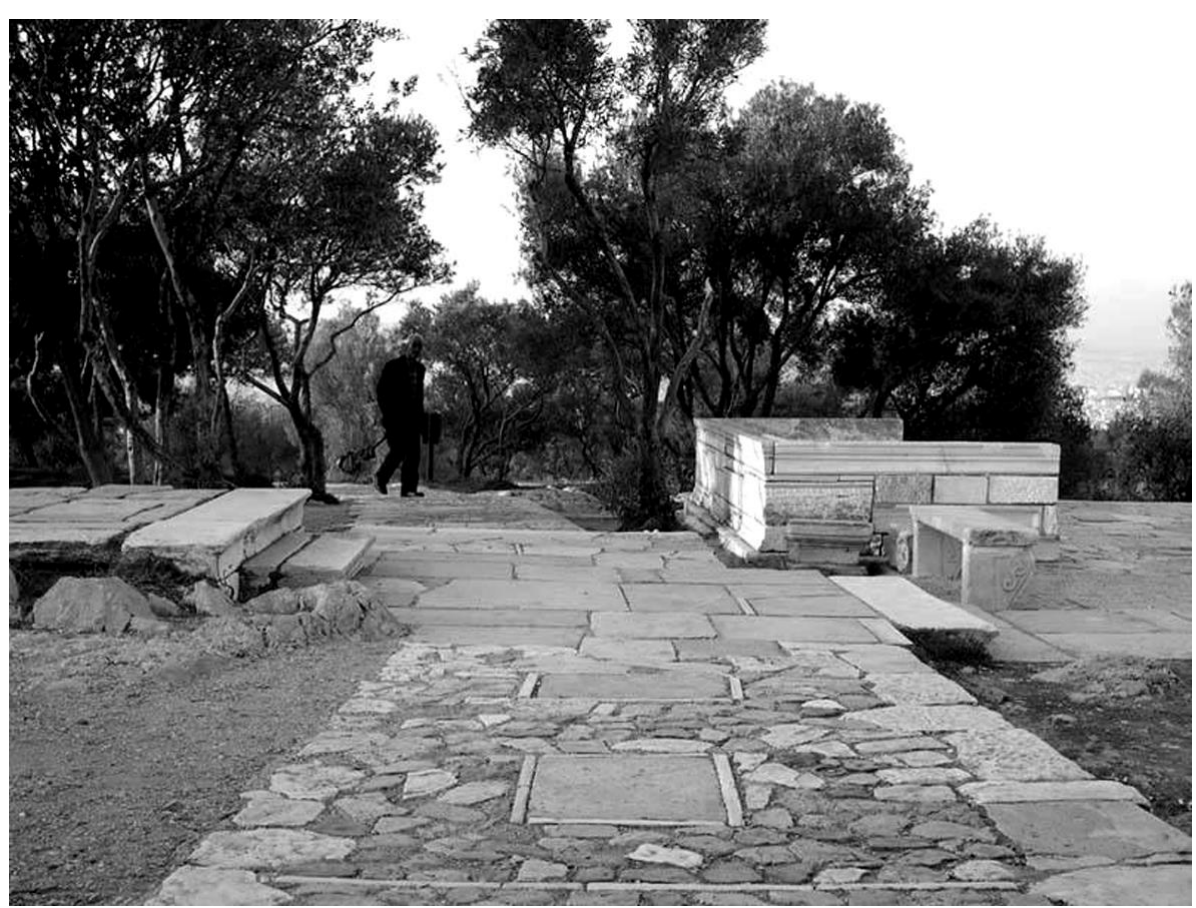

Figure 3. Dimitris Pikionis. The Philoppappos Hill. Athens

Source: Marko Peterlin.

In the monument to Walter Benjamin in Port Bou, the memory lies not in the style but in the subject of the site. Like the memorials to the victims of fascism designed by Bogdanović, the necessary memory does not burden the work with unnecessary pathos.

The cemetery at Finisterre is a place in search of memory. Cemeteries are places for remembering the dead, but nobody is buried in this one. However, the blocks of concrete recall the granite outcrops among the green landscape of Galicia, or megalithic monuments constructed by a strange civilisation. Perhaps, in the future, archaeologists will wonder about this outlandish place that looks like a cemetery, though one in which nobody was ever buried.

\section{Concerning Art}

Adolf Loos wrote that the purpose of architecture is to create spaces that should produce effects and arouse emotions. ${ }^{13}$ So a bank must inspire confidence in savers, a bedroom must have a cosy appearance, etc. According

13. Adolf Loos, On Architecture (Riverside, California: Ariadne Press, 2002), 84: „Architecture arouses moods in people, so the task of the architect ist to give these moods concrete expression. A room must look cozy, a house comfortable to live in. /.../ A bank must say, Here your money is safe in the hands of honest people." In German: "Die architektur erweckt stimmungen im menschen. Die augabe des architekten ist es daher, diese stimmung zu präzisieren. Das zimmer muss gemütlich, das Haus wohnlich aussehen. Das Justizgebäude muss dem heimlichen laster wie eine drohende gebärde erscheinen. Das bankhaus muss sagen: hier ist dein geld bei ehrlichen leuten fest und gut verwahrt." Adolf Loos, Architektur (Vienna: Adolf Opel ed., 1931), 102. 
to Loos, a space for being alone must also provoke the right emotions. But what are these emotions?

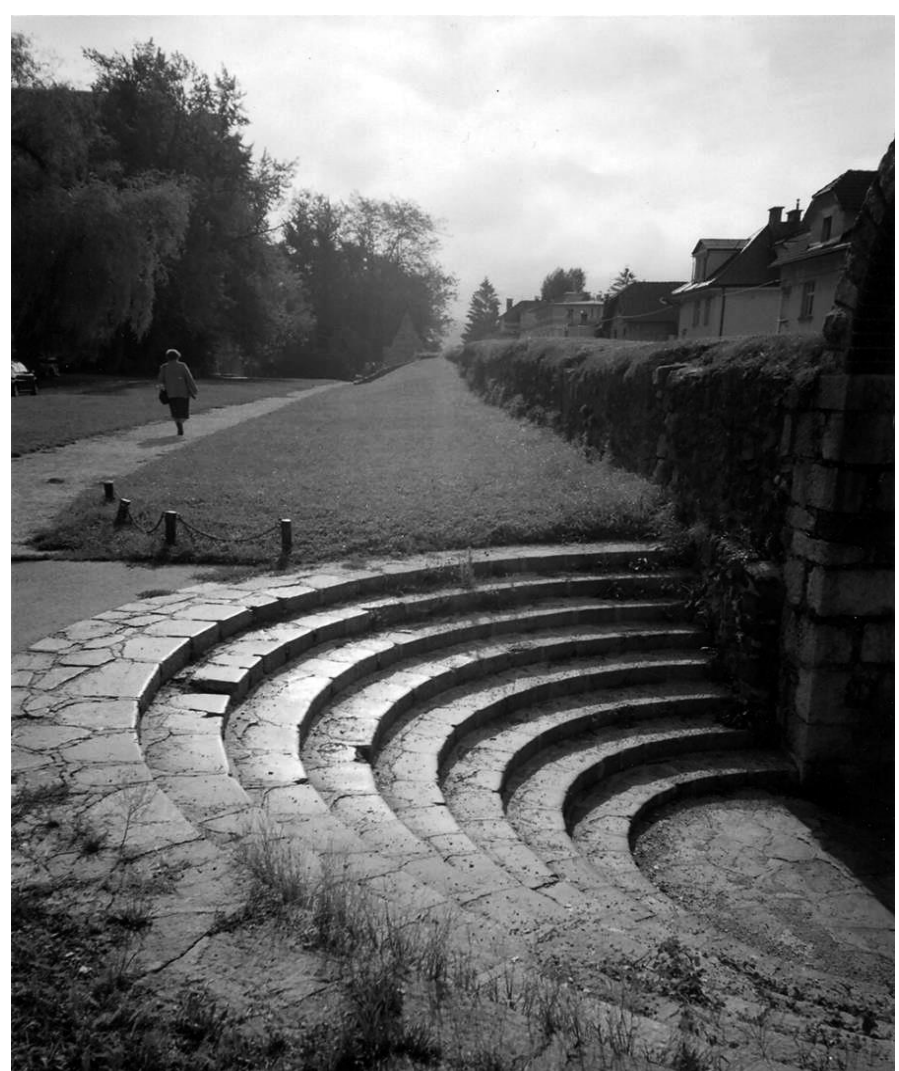

Figure 4. Jože Plečnik. The Roman Wall. Ljubljana

Source: Urša Komac.

What we probably expect from such spaces is that they should inspire serenity -serenity perhaps that comes from the familiar, from what we might call the classical (see Figure 4). The classical is what endures, what never goes out of fashion. It is characterised by harmony and balance, by its perfect proportions. Semper said that there have only been two original styles of architecture, the Greek and the Gothic, and that the Gothic came to an end with the cathedrals of the Middle Ages. This is a fairly precise statement, at least as far as Greek style is concerned. The world has changed more in the last 150 years than it did between Antiquity and Semper's time. Until then, the cultured architectural styles in the West, with the possible exception of the Gothic, have moved cyclically around certain elements that had been invented by the Greeks. ${ }^{14}$ Each style that insisted on a return to the classical was followed by

14. Adolf Loos, On Architecture (Riverside, California: Ariadne Press, 2002), 84. "Our culture is founded on an recognition of the absolute superiority of classical Antiquity. The technique of our thinking and feeling has been inherited from the Romans. From the Romans comes our social conscience and the discipline of the soul. It was not merely a matter of chance that the Romans were unable to discover a new order of columns, a new ornament. They were too advanced for that. They inherited everything from the Greeks and adapted it to their own ends." 
mannerist variations that evolved from it. Hellenism was a continuation of the original Classicism; the Renaissance was followed by Mannerism, and Mannerism by the Baroque; eighteenth-century Neo-Classicism developed into the Romanticism of the nineteenth century.

Classical perfection has to be ruined, in the literal sense of the word. And what better ruin than that of a Roman temple? Piranesi and Caspar David Friedrich were both aware of this. For, paradoxically, the best users of Classicism were perhaps the Mannerists, the Romantics who mixed, combined, juxtaposed, piled up, made and unmade; who to a certain extent perverted, or who used an immature Classicism (see Figure 5). Both Bogdanović and Plečnik were attracted by the Etruscan, in other words by the pre-classical or the potentially classical.

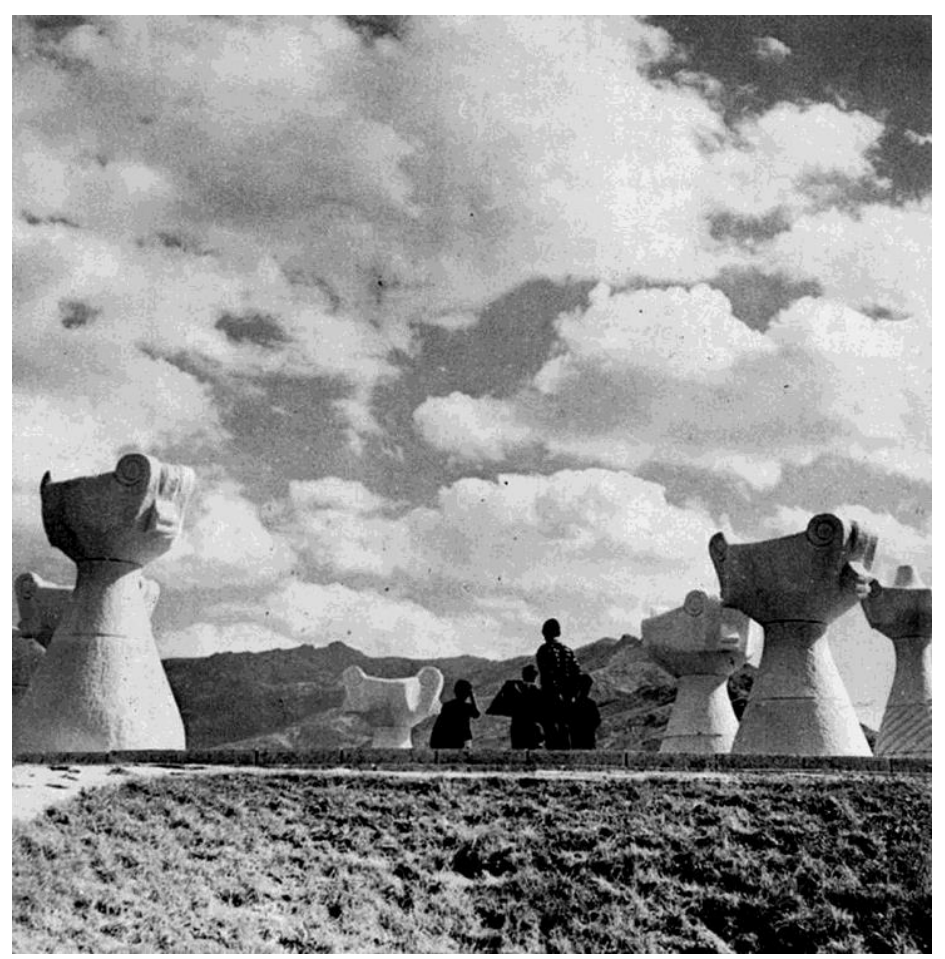

Figure 5. Bogdan Bogdanović. Cenotaphs in Prilep

Source: Bogdan Bogdanović.

\section{Bibliography}

Baroja, Pio. El árbol de la ciencia [The Three of Knowledge.] Ediciones Caro Raggio. Ediciones Catedra, 1994.

De Leon, Fray Luis. Retrieved from http://users.ipfw.edu/jehle/poesia/vidareti.htm. [19.9.2016].

"Die Chinesische Floete [The Chinese Flute.]" In CD Mahler Das Lied von der Erde (Milan: Erato Disques, S.A., 1992).

Fitzgerald, Edward. Rubáiyát of Omar Khayyám. London and Glasgow: Collins, 1947. Horace, The Complete Work of Horace. Translated by John Marshall. London: J .M. Dent \& Sons. New York: E. P. Dutton \& Co, 1908. 
Loos, Adolf. "Architektur [Architecture.]" In Loos, Adolf: Trotzdem.1900-1930. Edited by G. Prachnercop. Vienna, 1982.

Loos, Adolf. "Architecture (1910)." In On Architecture. Translated by Michael Mitchell. Riverside, California: Ariadne Press, 2002.

Nietzsche, Friedrich. Die Fröhliche Wissenschaft [The Gay Science.] Stuttgart: Alfred Kroner Verlag, 1921.

Nietzsche, Friedrich. The Gay Science. Section 280. Translated by Walter Kaufmann. New York: Vintage books. Random House, 1974.

Otero Pedrayo, Ramon. Guía de Galicia [Guide to Galicia.] Vigo: Editorial Galaxia, 1965.

Voltaire. "Memory's Adventure." In p. Candide, Zadig and selected stories. Translated by Donald M. Frame. . New York: A Signet Classic, 1961.

Wei, Wang. La montaña vacía [Laughing lost in the mountains.] Translated by Guillermo Dañino. Madrid: Ediciones Hiperión, 2004. 